\title{
Assessing the effect of focused direct and focused indirect written corrective feedback on explicit and implicit knowledge of language learners
}

\author{
Majid Nemati, Sayyed Mohammad Alavi and Hassan Mohebbi *i
}

\author{
${ }^{*}$ Correspondence: hassan. \\ mohebbi973@gmail.com \\ Faculty of Foreign Languages and \\ Literatures, University of Tehran, \\ Tehran, Iran
}

\begin{abstract}
This study investigates the effect of teacher's written corrective feedback (WCF) on acquisition of explicit and implicit knowledge of simple past tense by language learners. Eighty-seven Iranian beginner learners of English participated in this study. The participants were randomly assigned to three groups: focused direct WCF, focused indirect WCF, and control groups. The participants completed text summary tasks. They also took placement test, pretest narrative writing task, text summary tasks, pretest and posttest untimed grammaticality judgment test, metalinguistic test, and timed grammaticality judgment test. The results of the data analysis showed the positive effect of WCF on acquisition of explicit and implicit knowledge of simple past tense by Iranian beginner learners of English in an English as a foreign language classroom context. However, the findings of the study should be interpreted cautiously due to different factors involved in explicit and implicit acquisition of a structure and also the nature of a structure and its difficulty and complexity. The findings of the study are discussed in detail and future venues for research are suggested.
\end{abstract}

Keywords: Written corrective feedback, Explicit knowledge, Implicit knowledge, Interface hypothesis, Iranian language learners

\section{Introduction}

Since Truscott's arguments against the effect of written corrective feedback (WCF) on improving second language (L2) writing (Truscott, 1996, 1999, 2001, 2004, 2007, 2009, 2010) and Ferris's responses (Ferris, 1995, 1997, 1999, 2002, 2003, 2004, 2010, 2012, 2014), the effect of WCF on improving L2 learners' writing has been studied extensively from different perspectives. However, there are some aspects of WCF which are under-researched or not researched as needed. One of these issues is the potential role of WCF in acquisition of explicit and implicit knowledge. Lee (2013) argued that the WCF as a strategy to help L2 learners' language acquisition have been over-applied while there is no sufficient research evidence. To bridge the perceived gap, this study investigates the effect of focused direct and focused indirect written corrective feedback on explicit and implicit knowledge of Iranian language learners.

(c) The Author(s). 2019 Open Access This article is distributed under the terms of the Creative Commons Attribution 4.0 International License (http://creativecommons.org/licenses/by/4.0/), which permits unrestricted use, distribution, and reproduction in any medium, provided you give appropriate credit to the original author(s) and the source, provide a link to the Creative Commons license, and indicate if changes were made. 


\section{Explicit and implicit knowledge, interface hypothesis, and WCF}

One of the key issues in second language acquisition (SLA) is the role of explicit and implicit knowledge in L2 learning. In fact, the key point in explicit-implicit distinction is to assess the possibility of learning without awareness (Andringa \& Rebuschat, 2015). In other words, the main difference between explicit and implicit knowledge lies in the fact that whether learners are aware of what they know (Godfroid, Loewen, Jung, Park, Gass, \& Ellis, 2015).

Hulstijn (2005, p. 131) defines explicit and implicit learning as "Explicit learning is input processing with the conscious intention to find out whether the input information contains regularities and, if so, to work out the concepts and rules with which these regularities can be captured. Implicit learning is input processing without such as intention, taking place unconsciously".

Ellis (2005) classifies the key characteristics of implicit and explicit knowledge (Table 1).

Ellis (2004, 2005) acknowledges that L2 acquisition results in development of implicit knowledge. Although the relationship between explicit and implicit knowledge and their role in L2 learning has been a controversial issue, surprisingly enough, there is little discussion of explicit and implicit knowledge in the field of WCF. Therefore, the nature of explicit and implicit knowledge, the relationship between them and the procedure underlying these constructs, and the role of WCF in these two types of knowledge warrant further research and discussion.

In fact, this trend of research is rooted in the interface hypothesis, first introduced by Sharwood Smith (1981) and followed by DeKeyser (1998). The interface hypothesis becomes central to the issue of the effect of WCF on L2 development (Williams, 2012).

The interface hypothesis clarifies the relationship between explicit and implicit knowledge:

- The non-interface position: no transfer is possible between explicit and implicit knowledge. Krashen believes in this position arguing that explicit and implicit knowledge are distinct. Based on Krashen's no interface hypothesis, simple structures can be taught explicitly but complex structures cannot be taught explicitly and therefore can only be acquired implicitly (Ellis, 2005; TammengaHelmantel, Arends, \& Canrinus, 2014).

Table 1 Key characteristics of implicit and explicit knowledge (Adapted from Ellis, 2005)

\begin{tabular}{|c|c|c|}
\hline Characteristics & Implicit knowledge & Explicit knowledge \\
\hline Awareness & Intuitive awareness of linguistic norms & Conscious awareness of linguistic norms \\
\hline Type of knowledge & $\begin{array}{l}\text { Procedural knowledge of rules and } \\
\text { fragments }\end{array}$ & $\begin{array}{l}\text { Declarative knowledge of grammatical } \\
\text { rules and fragments }\end{array}$ \\
\hline Systematicity & Variable but systematic knowledge & Anomalous and inconsistent knowledge \\
\hline Accessibility & $\begin{array}{l}\text { Access to knowledge by means of } \\
\text { automatic processing }\end{array}$ & $\begin{array}{l}\text { Access to knowledge by means of } \\
\text { controlled processing }\end{array}$ \\
\hline Use of L2 knowledge & $\begin{array}{l}\text { Access to knowledge during fluent } \\
\text { performance }\end{array}$ & $\begin{array}{l}\text { Access to knowledge during } \\
\text { planning difficulty }\end{array}$ \\
\hline Self-report & Nonverbalizable & Verbalizable \\
\hline learnability & Potentially only within critical period & Any age \\
\hline
\end{tabular}


- The weak interface position: the transfer is possible under certain circumstances, such as when learner is psycholinguistically ready according to the developmental stage.

- The strong interface position: explicit knowledge can be transferred to implicit one through practice (Pawlak, 2014).

N. C. Ellis (2005) believes that implicit and explicit L2 learning are totally different and support various elements of L2 proficiency. Han and Finneran (2014) claim that the three types of relationship between explicit and implicit knowledge coexist and different aspects of grammar might be susceptible to different interface relation. Akakura (2012) assessed the effect of explicit instruction on implicit and explicit knowledge and found that explicit instruction had an impact on implicit knowledge.

Ellis (2002) in a review of the research investigating whether form-focused instruction (FFI) affects the acquisition of implicit knowledge, concludes that the findings only provide evidence that FFI contributes to implicit knowledge at above beginner proficiency levels and the issue of whether FFI works for the beginner learners is not answered yet. Also, he highlights two points which should be paid close attention in the studies examining this issue: the target structure and the duration of instruction.

Considering the role of explicit and implicit knowledge in WCF, we should take into account the differences between oral and written corrective feedback too. Pawlak (2014) summarizes the key differences between oral and written corrective feedback. Table 2 presents the differences between oral and written corrective feedback.

Similarly, Sheen (2010) summarized the differences between oral and written corrective feedback. She highlighted that in contrast to oral corrective feedback, WCF force is clear, it is delayed, and each learner is exclusively exposed to WCF limited to his or her errors.

Table 2 Key differences between oral and written corrective feedback (Adapted from Pawlak, 2014)

\begin{tabular}{|c|c|}
\hline Oral corrective feedback & Written corrective feedback \\
\hline Corrective force may not always be clear & Corrective force is usually clear \\
\hline The feedback is publically available & Feedback only on one's own errors \\
\hline $\begin{array}{l}\text { The feedback is provided online and offline } \\
\text { (i.e., immediate and delayed) }\end{array}$ & The feedback is provided only offline (i.e., it is delayed) \\
\hline $\begin{array}{l}\text { Relatively straightforward focus (i.e., target } \\
\text { language form) }\end{array}$ & $\begin{array}{l}\text { Considerable complexity of focus (i.e., many aspects of } \\
\text { second language writing) }\end{array}$ \\
\hline $\begin{array}{l}\text { Both input-providing (e.g. recast) or output- } \\
\text { inducing (e.g. clarification request) corrective } \\
\text { techniques are available }\end{array}$ & $\begin{array}{l}\text { Both input-providing (direct correction) or output-inducing } \\
\text { (indirect correction) corrective techniques are available }\end{array}$ \\
\hline $\begin{array}{l}\text { The feedback can be explicit (overt) as well } \\
\text { as implicit (covert) }\end{array}$ & $\begin{array}{l}\text { The feedback can only be explicit (overt) as the intervention } \\
\text { is evident }\end{array}$ \\
\hline $\begin{array}{l}\text { The correction can be conducted by the } \\
\text { teacher, the learner who erred, or a peer }\end{array}$ & $\begin{array}{l}\text { The correction can be conducted by the teacher, the learner } \\
\text { who erred, or a peer }\end{array}$ \\
\hline Metalinguistic information possible & Metalinguistic information possible \\
\hline Conversational or didactic & Mostly didactic \\
\hline $\begin{array}{l}\text { Possible direct impact on implicit, } \\
\text { procedural knowledge }\end{array}$ & Only explicit, declarative knowledge affected in the main \\
\hline
\end{tabular}


Regarding WCF, in line with Krashen, Truscott has repeatedly, almost in all of his articles, mentioned that WCF can only help L2 learners develop explicit or declarative knowledge not implicit knowledge which is the ultimate goal of SLA (Bitchener \& Knoch, 2015). Shintani and Ellis (2013) pinpoint that the potential contribution of WCF in explicit and implicit knowledge is the key question of L2 writing and SLA interface. Polio (2012) emphasized on an urgent need to establish a research agenda on the relationship between WCF and explicit and implicit knowledge.

Pawlak (2014) depicts the potential role of oral and written corrective feedback in explicit and implicit knowledge acquisition of L2 learners. Figure 1 presents this relationship. As Fig. 1 clearly represents, through WCF, it is possible to transfer explicit knowledge to implicit one.

Bitchener (2012) claimed that we know that WCF plays a role in L2 explicit knowledge development, but Bitchener and Knoch (2015) underscored that there is a perceived gap studying the potential effect of WCF in converting explicit knowledge to implicit. Li (2014) found that the efficacy of oral corrective feedback was constrained by the explicitness of feedback provided, the proficiency level of learners, and the nature of the target linguistic structure. Williams (2012) claimed that the major contribution of WCF is in explicit knowledge not implicit one.

To our knowledge, to date, there are only two studies examining the effect of WCF on acquisition of explicit and implicit knowledge. Shintani and Ellis (2013) investigated the effect of direct WCF and metalinguistic explanation on learners' explicit and implicit knowledge. Surprisingly enough, the data analysis showed that direct WCF had no impact on explicit and implicit knowledge of the target structure which was the English indefinite article; however, metalinguistic explanation helped the learners develop explicit knowledge of the target structure but the effect was not significantly durable indicating that it did not have any effect on implicit knowledge.

In an Iranian context, Rezazadeh, Tavakoli, and Eslami Rasekh (2015), as a replication of Shintani and Ellis (2013), examined the effect of direct WCF and metalinguistic explanation on explicit and implicit acquisition of English definite and indefinite articles of EFL learners. The data analysis revealed the positive effect of metalinguistic explanation on explicit and implicit knowledge.



Fig. 1 Potential contributions of oral and written corrective feedback to explicit and implicit knowledge 


\section{Measures of explicit and implicit knowledge}

To date, there is no pure measure of explicit and in particular implicit knowledge, especially in L2 learning (Ellis, 2005). Ellis (2005) summarized the design features of tests measuring explicit and implicit knowledge (Table 3).

Ellis (2005) found that the elicited imitation and the metalinguistic knowledge tests were the best measures of implicit and explicit knowledge. However, almost after a decade, Spada, Shiu, and Tomita (2015) in a validation study cast doubt on the construct validity of elicited imitation task as a measure of implicit knowledge.

Godfroid et al. (2015) studied whether timed and untimed grammaticality judgment tests measure explicit and implicit knowledge through eye-tracking. They observed that timed and untimed grammaticality judgment tests were distinct instruments for measuring implicit and explicit knowledge separately.

However, as Polio (2012) rightly mentioned, any L2 writing task, even performed under time constraints and pressure, may use both explicit and implicit knowledge. She assumes that WCF increases explicit knowledge.

To date, the target structures of most of research in this field were indefinite and definite articles and the arguments for and against the effectiveness of WCF are based on findings of them. However, it seems that a WCF strategy working for article error might not work for other complex structures.

Shintani and Ellis (2013) argued that we do not know whether WCF benefits explicit knowledge, and there is not enough research that has exclusively investigated the impact of WCF on L2 explicit knowledge and implicit knowledge. Given the lack of robust research findings about the effect of WCF on explicit and implicit knowledge, we do need to do more studies to shed more light on this issue too.

\section{Research questions}

This study investigates the following two research questions:

- $\mathrm{RQ}_{1}$ : Is there any difference between focused direct feedback and focused indirect feedback in terms of improving the accurate use of simple past tense by beginner L2 learners in writing?

- $\mathrm{RQ}_{2}$ : Do focused direct feedback and focused indirect feedback have any effect on beginner L2 learners' acquisition of explicit and implicit knowledge of simple past tense?

Table 3 Design features of explicit and implicit tests (Adapted from Ellis, 2005a, 2005b)

\begin{tabular}{llllll}
\hline Criterion & Imitation & $\begin{array}{l}\text { Oral } \\
\text { narrative }\end{array}$ & $\begin{array}{l}\text { Timed grammaticality } \\
\text { judgment test }\end{array}$ & $\begin{array}{l}\text { Untimed grammaticality } \\
\text { judgment test }\end{array}$ & Metalanguage \\
\hline $\begin{array}{l}\text { Degree of } \\
\text { awareness }\end{array}$ & Feel & Feel & Feel & Rule & Rule \\
$\begin{array}{l}\text { Time available } \\
\begin{array}{l}\text { Focus of } \\
\text { attention }\end{array}\end{array}$ & Pressured & Pressured & Pressured & Unpressured & Unpressured \\
$\begin{array}{l}\text { Metalinguistic } \\
\text { knowledge }\end{array}$ & No & Meaning & Form & Form & Form \\
\hline
\end{tabular}




\section{Method \\ Participants}

For this research, 145 male and female learners of English studying in language institutes in Ardabil, Iran, sat for an English placement test to check their level. According to the aim of the study and based on the result of this test, 87 learners (35 female learners and 52 male learners) who were in beginner level of English proficiency were selected. The participants were 12-16 years old and bilingual in Azeri-Turkish, as their mother tongue, and Persian, as the formal language of the country and instruction in Iranian schools and universities. The participants were middle school students. The participants were randomly divided into three different participating groups: focused direct WCF $(n=27)$, focused indirect WCF $(n=29)$, and control $(n=31)$.

\section{Target structure}

The majority of the L2 studies to date investigating the effect of feedback on enhancing L2 writing have exclusively focused on definite and indefinite articles. However, there are other structures and forms which are as important as articles in enhancing the quality of L2 writing, namely tenses, modal auxiliary verbs, active and passive forms, connectives, and conditional sentences.

Moreover, in selecting the target structure of the study and based on the L2 proficiency of the participants two points, namely the problematicity and the learnability of the target structure need to be considered. Furthermore, learners' developmental readiness in choosing the target structure and also in feedback strategy should be considered. Also, as Ferris (2002) suggested, we chose the rule-governed items or rule-based error categories, i.e., verb tense, article usage for which focused feedback would presumably be more beneficial, in particular in case of learners of lower language proficiency (Lee, 2013). The target structures were also treatable errors subjected to self-correction by learners as they were rule-governed (Lee, 2013). Ferris (2002) gave a dichotomy between treatable errors, which are related to a linguistic structure which occurs in a rule-governed and a learner can self-correct it resorting to a grammar book or rules, and untreatable errors, such as word choice errors which are idiosyncratic and lead a learner to use acquired knowledge to correct them. Bitchener and Knoch (2010) argued that rule-based errors may be more effectively corrected with feedback than complex errors. However, he warned that this is just a theoretical possibility which needs to be tested. Therefore, the issue of whether different feedback strategies should be used for different hard or easy grammatical structures needs more in depth investigation.

Van Beuningen, De Jong, and Kuiken (2012) classified errors into two groups including grammatical errors such as syntactic and morphological ones and non-grammatical errors like punctuation and spelling and indicated that direct WCF was more beneficial for grammatical errors and indirect WCF for non-grammatical errors.

Ferris (2002) rightly argued that teachers need to study and provide feedback on aspects of grammar which are problematic for L2 learners such as different verb tenses, active and passive voices, verb types, auxiliary forms, types of nouns, subject-verb agreement, articles, and basic clause and sentence patterns. In sum, past simple (regular -ed) was the target structure of this study. 


\section{Instruments}

Placement test

To check the L2 proficiency of participants to choose the beginner learners, the participants sat for Oxford Solutions Placement Test. The test includes three sections: grammar and vocabulary, reading, and writing. Table 4 shows the cut scores of the test.

\section{Pretest narrative writing task}

To get assurance as the homogeneity of the participating groups in terms of writing, a pretest narrative writing task was administered. The participants needed to do a picture description task titled "Four Journeys" taken from Heaton's (1975) book titled "Beginning composition through pictures". The writings were scored based on ESL composition profile of Jacobs (1981).

\section{Text summary tasks}

Following Raimes (1983) and Stefanou and Revesz (2015), text summary task was used to elicit the target structure in learners' writing. The participants were required to read a text and then summarize the text. Four texts were adopted from Further Stories for Reading Comprehension A by Hill (1988) for the treatment sessions. I chose the texts which had obligatory contexts for using regular simple past tense. The texts were checked for the readability index too. The Flesch Reading Ease Scores of the texts were between 60 and 89 which indicated that the texts were appropriate for the beginner learners. Another two text summary tasks were used as immediate and delayed posttests.

\section{Untimed grammaticality judgment test}

Following Akakura (2012), Ellis, Loewen, and Erlam (2006), and Gutierrez (2013), untimed grammaticality judgment test was designed to tap the participants' explicit knowledge of the target structure. It was a pen-and-paper test and participants were given unlimited time to judge sentences in terms of grammaticality. The participants were required to:

- Decide and report whether each sentence is grammatically correct or not

- Make a decision on the degree of certainty of their judgment by writing a score from 0 to $100 \%$ in the section provided

- and report whether they use a rule or feel for each sentence

Learners were given one model sentence to practice before administering the test which is explained by the teacher/researcher. There were 15 items: ten were incorrect and five were correct. Each item was given on a new sheet and the test-takers were not

Table 4 Cut scores of oxford solutions placement test

\begin{tabular}{lllll}
\hline & Total & Elementary & Pre-intermediate & Intermediate \\
\hline Grammar and vocabulary & 50 & $0-20$ & $21-30$ & $31+$ \\
Reading & 10 & $0-4$ & $5-7$ & $08+$ \\
writing & 10 & $0-4$ & $5-7$ & $08+$ \\
\hline
\end{tabular}


allowed to turn back and look at any part of the test they had already answered. The responses were scored as either correct ( 1 point) or incorrect ( 0 point). Two versions of the test were developed for pretest and posttest.

\section{Metalinguistic knowledge test}

As another test of explicit knowledge, the test-takers were presented with ten sentences and were informed that the sentences were ungrammatical. They were required to correct the error and explain what was wrong with the sentences in Persian. Like the grammaticality judgment test, they had no permission to turn back and look at any part of the test they had already answered. One point was given for correcting the error and one point for a correct explanation of the error. Two versions of the test were developed for pretest and posttest.

\section{Timed grammaticality judgment test}

Although elicited imitation is proved as the most reliable and valid measure of implicit knowledge (Ellis, 2005; Sarandi, 2015; Yan, Maeda, Lv, \& Ginther, 2016), due to practicality/feasibility concerns, I used timed grammaticality judgment test as a measure of implicit knowledge. It is argued that when learners are asked to do the grammaticality judgment test task under time constraints, they need to tap into their implicit knowledge, not explicit one. The test format and instruction and grading was like untimed grammaticality judgment test except the time constraint imposed on this test. There were 15 items: ten were incorrect and five were correct. Two versions of the test were developed for pretest and posttest.

\section{Procedures}

Firstly, a pilot study was conducted to check any potential gap in the design and procedure of the study. We asked three researchers to check the validity of the instruments designed. Moreover, 15 beginner learners with similar characteristics of the participants of the main study took the tests to check the timing of each test, the items, the wording and format, and the reliability of the tests.

We asked the volunteered participants to sign the informed consent form to express their satisfaction with their volunteer participation in the study. At time 1, the participants signed the informed consent form and sat the placement test to check their proficiency level: beginner based on the cut scores of the test. They also did the pretest narrative writing task to check and guarantee the homogeneity of the groups in terms of writing ability. Then, the participants were divided randomly into their respective groups. At time 2, the participants were required to take pretest untimed grammaticality judgment test and pretest metalinguistic knowledge test, as measures of their explicit knowledge test of the target structures. The participants were assumed to not be able to pass the test. At time 3, the participants performed the pretest timed grammaticality judgment test, as a measure of implicit knowledge. Table 5 represents the participating groups, feedback type, and the target structure.

At time 4 , each group did the text summary task 1 . The readability of the original texts was checked to be in the participating groups' proficiency level. They had $20 \mathrm{~min}$ to complete the task. At time 5, 3 days later, each group received their text which 
Table 5 Participating groups and target structure

\begin{tabular}{llll}
\hline Groups & Proficiency & Feedback type & Target structure of phase 1 \\
\hline Experimental group 1 & Beginner & Focused direct & Simple past (regular -ed) \\
Experimental group 2 & Beginner & Focused indirect & Simple past (regular -ed) \\
Control group 1 & Beginner & - & - \\
\hline
\end{tabular}

received feedback based on their respective group: focused direct feedback, focused indirect feedback, or no feedback. The experimental groups had 5 min to study the feedbacks provided by the researcher; then, their text were gathered and they were given another sheet to revise a clean copy of the original text. Then, they did the second writing task. They read the text, then the text was gathered and they needed to write a summary of the text. At times 6 and 7, the procedure was like time 5 .

At time 8 , they reviewed their text coupled with feedbacks and they revised the text. At time 9, they took the immediate posttest text summary task. After 3 weeks, at time 10, they were given the delayed posttest text summary task to measure the effectiveness of the treatment in terms of feedback effectiveness. At time 11, they took delayed posttest untimed grammaticality judgment test and delayed posttest metalinguistic knowledge test to measure the explicit knowledge of the target structure. And finally, at time 12 , they were given the delayed posttest timed grammaticality judgment test as a measure of implicit knowledge of the target structure. It should be mentioned that the control groups at each proficiency level did the tasks like the other experimental groups but did not receive any feedback.

The teachers were informed about the aim of the study and were requested not to teach the target structure during data collection and treatment sessions. For eliminating the task effect, writing tasks were counterbalanced; each group was divided into three sub-groups receiving tasks in different order. Based on Lee's (2013) suggestion, we provided timely feedback, the less delay in giving feedback might be better for learners. The learners received their manuscript provided feedback after 3 days (Fig. 2).

\section{Results}

The data was analyzed running different statistical analyses based on the nature of data and the research questions. Also, following Shintani, Ellis, and Suzuki (2014), accuracy was calculated based on Pica's (1994) formula for target-like use:

$$
\text { Accuracy }=\frac{\text { number of grammatical morphemes supplied correctly }}{\text { number of obligatory contexts }+ \text { number of overused forms }} \times 100
$$

To check the reliability of scoring, one-third of the writings were scored by one teacher and the inter-rater reliability was calculated. The inter-rater reliability was .98 .

A one-way ANOVA run on the scores from the placement test confirmed that there was no significant difference across the three participating groups. Also, the analysis of the data obtained from the pretest narrative writing task indicated that there was no significant difference among the participating groups.

The result of pretest untimed and timed grammaticality judgment tests and metalinguistic knowledge test confirmed that the participants had no explicit and implicit knowledge of the target structure of this study, i.e., simple past tense (regular -ed). 


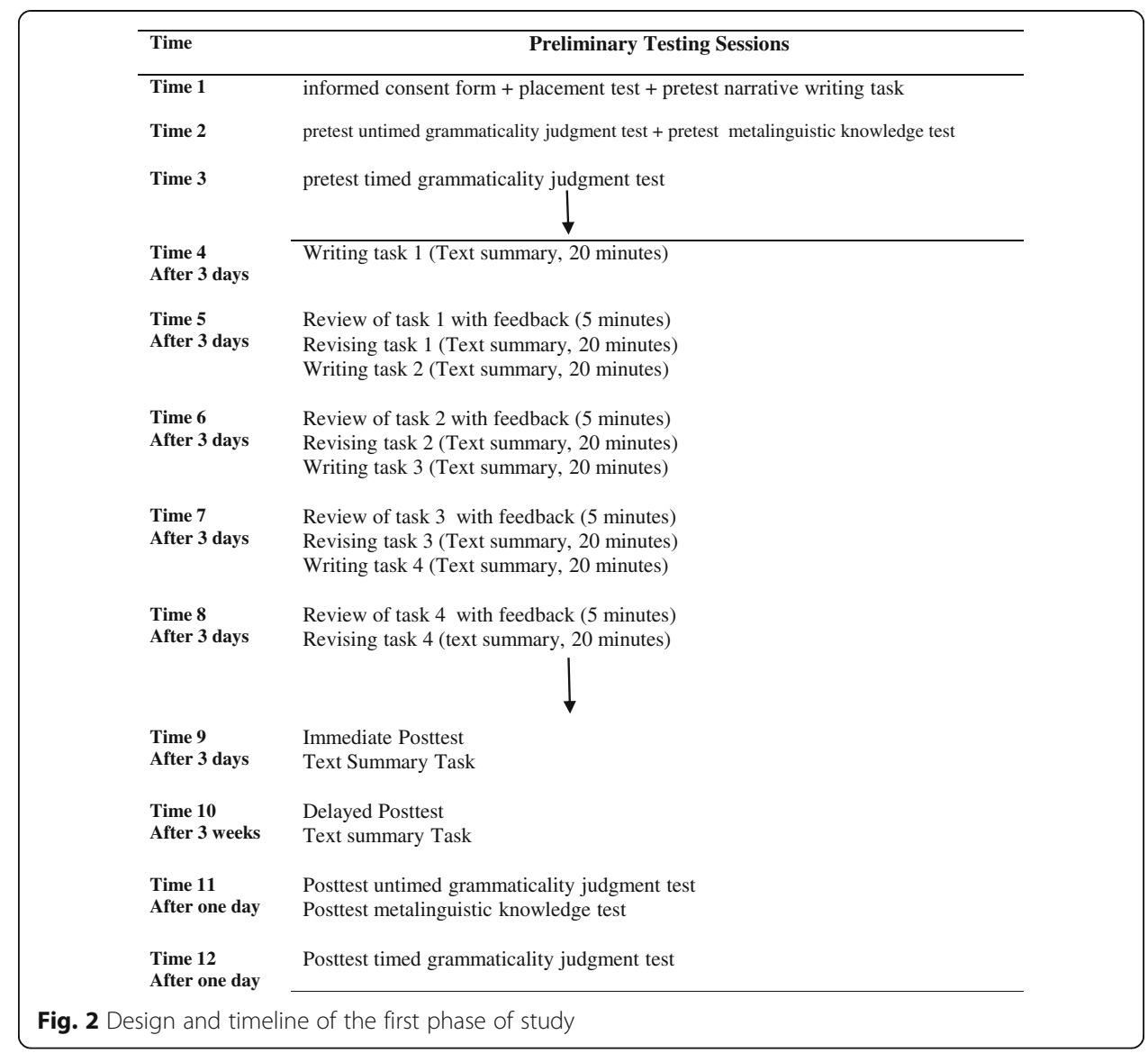

\section{Narrative writing and text summary tasks}

Table 6 represents the descriptive statistics for the narrative writing task and text summary test.

The result of one-way ANOVA revealed that there was no statistically significant difference among the three groups on the narrative writing task, $F(2,84)=2.83, p=.06$. The results of repeated measures ANOVA on the scores obtained from the narrative writing task and text summary test showed a significant main effect for time with a big effect size, $F=88.54, p<.001, \mathrm{n}_{\mathrm{p}}{ }^{2}=.68$ and a main significant effect for WCF treatment with a big effect size, $F(2)=105.11, p<.001, \mathrm{n}_{\mathrm{p}}{ }^{2}=.71$. Also, a significant interaction effect was observed between time and WCF treatment with a big effect size, $F=35.39$, $p<.001, \mathrm{n}_{\mathrm{p}}{ }^{2}=.46$. Table 7 summarizes the results of repeated measures ANOVA for the narrative writing task and the text summary test.

Table 6 Descriptive statistics for the narrative writing task and text summary

\begin{tabular}{|c|c|c|c|c|c|c|c|}
\hline \multirow{2}{*}{$\begin{array}{l}\text { Treatment } \\
\text { WCF }\end{array}$} & \multirow[t]{2}{*}{$n$} & \multicolumn{2}{|c|}{ Pretest } & \multicolumn{2}{|c|}{ Posttest 1} & \multicolumn{2}{|c|}{ Posttest 2} \\
\hline & & $\bar{M}$ & $S D$ & $\bar{M}$ & $S D$ & $\bar{M}$ & $S D$ \\
\hline Focused direct & 27 & 39.18 & 4.29 & 70.33 & 12.87 & 57.59 & 12.66 \\
\hline Focused indirect & 29 & 40.86 & 5.30 & 48.24 & 15.56 & 35.48 & 11.76 \\
\hline Control & 31 & 37.70 & 5.58 & 22.87 & 9.88 & 16.41 & 7.47 \\
\hline Total & 87 & 39.21 & 5.23 & 46.05 & 23.31 & 35.55 & 19.93 \\
\hline
\end{tabular}


Table 7 The results of repeated measures ANOVA for the narrative writing task and text summary test

\begin{tabular}{llll}
\hline Effect & $F$ & $p$ & $\eta_{p}{ }^{2}$ \\
\hline Treatment & 105.11 & $.001^{* *}$ & .71 \\
Time & 62.62 & $.001^{* *}$ & .68 \\
Treatment*Time & 6.18 & $.001^{* *}$ & .46 \\
\hline
\end{tabular}

The result of post-ANOVA analysis and pairwise mean comparisons showed that the difference between the focused direct and the focused indirect group was significant, $p<.001$. The difference between the focused direct and control group was significant, $p<.001$. There was also a statistically significant difference between the focused indirect group and the control group, $p<.001$. Table 8 shows the SPSS output for the post-ANOVA analysis for the narrative story task and the text summary test.

The results of the post-ANOVA analysis (Bonferroni adjustment) comparing groups in the posttests 1 and 2, as shown in Table 8, indicated that the focused direct group outperformed the focused indirect and the control groups in the posttest 1 and 2, indicating a significant difference between them, $p<.001$ in both testing times. Additionally, the focused indirect group performed better than the control group in the posttest 1 and 2 with a significant difference in both testing times, $p<.001$.

\section{Untimed grammaticality judgment test and metalinguistic knowledge test}

Table 9 presents the descriptive statistics for the untimed grammaticality judgment test.

A one-way ANCOVA was run to compare the impact of direct and indirect focused WCF on beginner L2 learners' acquisition of explicit knowledge of simple past tense. The data analysis indicated that there was a significant difference between the two experimental groups on post-intervention scores on untimed grammaticality judgment test with a large effect size, $F(2,83)=20.07, p<.001, \mathrm{n}_{\mathrm{p}}{ }^{2}=.32$.

Pairwise mean comparisons (Bonferroni) was run to statistically determine the significant differences among the groups. The analysis indicated that the difference between the focused direct feedback and focused indirect feedback groups was significant, $p<.001$. Similarly, there was significant difference between the focused direct feedback and control groups, $p<.001$. However, the difference between the focused indirect feedback and the control group was not significant, $p=.06$. The results obtained from untimed grammaticality judgment test analysis indicated that the focused direct feedback was more effective on beginner L2 learners' acquisition of explicit knowledge of simple past tense (Table 10).

Table 8 SPSS output for the post-ANOVA analysis for the narrative writing task and text summary test

Posttest 1: focused direct $>$ focused indirect $>$ control

Posttest 2: focused direct $>$ focused indirect $>$ control

\begin{tabular}{ll}
\hline Posttest 1 & Posttest 2 \\
\hline Focused direct $>$ focused indirect & Focused direct $>$ focused indirect* $^{*}$ \\
Focused direct $>$ control ${ }^{*}$ & Focused direct $>$ control ${ }^{*}$ \\
Focused indirect $>$ control & Focused indirect $>$ control \\
\hline
\end{tabular}


Table 9 Descriptive statistics for the untimed grammaticality judgment test

\begin{tabular}{|c|c|c|c|c|c|}
\hline \multirow{2}{*}{$\begin{array}{l}\text { Treatment } \\
\mathrm{CF}\end{array}$} & \multirow[t]{2}{*}{$n$} & \multicolumn{2}{|l|}{ Posttest } & \multicolumn{2}{|l|}{ Posttest } \\
\hline & & Unadjusted $M$ & $S D$ & Adjusted $M$ & Std. Error \\
\hline Focused direct & 27 & 4.51 & 2.37 & 4.61 & .29 \\
\hline Focused indirect & 29 & 3.10 & 2.09 & 3.03 & .28 \\
\hline Control & 31 & 2.09 & 1.51 & 2.07 & .27 \\
\hline
\end{tabular}

Metalinguistic knowledge test was also used to examine the effect of focused direct feedback and focused indirect feedback on beginner L2 learners' acquisition of explicit knowledge of simple past tense. The descriptive statistics for the metalinguistic knowledge test is presented in Table 11.

A one-way ANCOVA run on the metalinguistic knowledge test indicated that there was a significant difference between the two experimental groups on post-intervention scores on metalinguistic knowledge test with a large effect size, $F$ $(2,83)=35.29, p<.001, \mathrm{n}_{\mathrm{p}}{ }^{2}=.46$.

Pairwise mean comparison (Bonferroni adjustment) was conducted to statistically pinpoint the significant differences among the groups. The results revealed that there was a significant difference between the focused direct feedback and focused indirect feedback groups, $p<.001$. Similarly, the difference between the focused direct feedback and control groups was significant, $p<.001$. While, the difference between the focused indirect feedback and the control group was not significant, $p=.08$. In other words, similar to the results obtained from untimed grammaticality judgment test, the results from metalinguistic knowledge test analysis also indicated that the focused direct feedback group outperformed the other two groups involved in the study concerning beginner L2 learners' acquisition of explicit knowledge of simple past tense (Table 12).

\section{Timed grammaticality judgment test}

Table 13 demonstrates the descriptive statistics for the timed grammaticality judgment test.

The result of one-way ANCOVA indicated that there was a significant difference between the two experimental groups on post-intervention scores on timed grammaticality judgment test with a large effect size, $F(2,83)=18.03, p<.001, \mathrm{n}_{\mathrm{p}}{ }^{2}=.30$.

Post-hoc tests (Bonferroni adjustment) indicated that the focused direct WCF group performed better than the focused indirect WCF group and the difference between them was significant, $p<.002$. The difference between the focused direct WCF and control group was also significant, $p<.001$. However, there was no significant difference between the focused indirect WCF and control group, $p=.07$. Therefore, the focused direct WCF group outperformed the focused indirect WCF and control groups and

Table 10 Results of one-way ANCOVA for untimed grammaticality judgment test

\begin{tabular}{lllllll}
\hline Source & SS & $d f$ & MS & $F$ & $p$ & $\eta_{p}^{2}$ \\
\hline Pretest & 14.96 & 1 & 14.96 & 61.53 & .000 & .42 \\
Group & 93.92 & 2 & 46.96 & 20.07 & .000 & .32 \\
Error & 19.17 & 83 & 2.33 & & & \\
Total & 1305.00 & 87 & & & & \\
\hline
\end{tabular}


Table 11 Descriptive statistics for the metalinguistic knowledge test

\begin{tabular}{|c|c|c|c|c|c|}
\hline \multirow{2}{*}{$\begin{array}{l}\text { Treatment } \\
\text { CF }\end{array}$} & \multirow[t]{2}{*}{$n$} & \multicolumn{2}{|l|}{ Posttest } & \multicolumn{2}{|l|}{ Posttest } \\
\hline & & Unadjusted $M$ & $S D$ & Adjusted $M$ & Std. Error \\
\hline Focused direct & 27 & 4.14 & 2.36 & 4.15 & .28 \\
\hline Focused indirect & 29 & 1.82 & 1.16 & 1.84 & .27 \\
\hline Control & 31 & 1.03 & .65 & 1.00 & .26 \\
\hline
\end{tabular}

appeared to be the most effective WCF on beginner L2 learners' acquisition of implicit knowledge of simple past tense (Table 14).

\section{Discussion}

Generally, L2 teachers devote too much time and energy to give WCF on their learners' writing in hope of improving their writing. WCF is one of the most debated issues in L2 learning. To provide counterevidence to the claim of Truscott on the ineffectiveness of WCF, a great deal of research has been conducted.

Regarding the first research question, the findings of this study revealed the positive effect of WCF on improving the accuracy of learners' writing. This finding is in line with the previous studies such as Bitchener (2008), Bitchener and Knoch (2008, 2009a, 2009b, 2015), Bitchener, Young, and Cameron (2005), and Ferris (2015).

According to this finding, it can be argued that giving WCF, in this case focused direct and indirect WCF, on learners' writing can result in enhancing the accuracy of learners' writing. As it seems, focused WCF can be more effective for learners with low proficiency levels because they might not be able to decode unfocused WCF which is given on different range of structures and aspects of writing. Accordingly, it might be claimed that teachers should give focused WCF on beginner learners' writing to support their writing.

However, one of the key issues in WCF is which strategy of WCF is more effective in improving learners' writing. As the data obtained showed, the participants who received focused direct WCF outperformed their peers who received focused indirect WCF. This result indicates the positive effect of direct WCF. Like focused WCF, direct WCF can be more effective for beginner L2 learners as they might not have enough L2 proficiency and mastery of target structures to sort out indirect WCF. In sum, regarding the first research question, it can be argued that providing focused direct WCF for beginner learners of English can be more effective than indirect WCF.

Regarding the second research question, the data obtained from the timed and untimed grammaticality judgment tests and metalinguistic knowledge test lent support to the positive effect of focused direct WCF on acquisition of explicit and implicit knowledge of simple past tense (regular-ed).

Table 12 Results of one-way ANCOVA for metalinguistic knowledge test

\begin{tabular}{lllllll}
\hline Source & SS & $d f$ & MS & $F$ & $p$ & $\eta_{p}^{2}$ \\
\hline Pretest & 18.94 & 1 & 18.94 & 8.85 & .004 & .09 \\
Group & 150.99 & 2 & 75.49 & 35.29 & .000 & .46 \\
Error & 177.57 & 83 & 2.13 & & & \\
Total & 344.92 & 87 & & & & \\
\hline
\end{tabular}


Table 13 Descriptive statistics for the timed grammaticality judgment test

\begin{tabular}{|c|c|c|c|c|c|}
\hline \multirow{2}{*}{$\begin{array}{l}\text { Treatment } \\
\text { CF }\end{array}$} & \multirow[t]{2}{*}{$n$} & \multicolumn{2}{|l|}{ Posttest } & \multicolumn{2}{|l|}{ Posttest } \\
\hline & & Unadjusted $M$ & $S D$ & Adjusted $M$ & Std. Error \\
\hline Focused direct & 27 & 2.44 & 1.39 & 2.50 & .17 \\
\hline Focused indirect & 29 & 1.72 & 1.03 & 1.60 & .171 .00 \\
\hline Control & 31 & .68 & 1.05 & .16 & \\
\hline
\end{tabular}

The positive effect of WCF on explicit and implicit knowledge can be supported by Swain's output hypothesis (Swain, 1985, 1995). As Swain argued, output, in our case, writing, WCF, and revision, has a metalinguistic function which triggers and facilitates noticing and explicit and implicit acquisition of a target structure. WCF paves the way for syntactic processing which can result in acquisition.

Similarly, this finding can be justified by Schmidt's noticing hypothesis (Schmidt, 1990). According to Schmidt, attention and awareness are vital for learning; so, WCF can trigger attention which can result in learning. Likewise, Anderson's adaptive control of thought (ACT) (Anderson, 1983, 1985) considers acquisition a gradual transition from explicit knowledge to implicit knowledge. This transition was observed in this study in which WCF helped the learners acquire explicit knowledge of the target structure and then this explicit knowledge transformed into implicit knowledge.

Accordingly, it can be argued that teachers can use focused direct WCF to teach a new target structure. But, it would be foolhardy and misleading to believe that it is an easy task to accomplish.

As already mentioned, one of the problems in this field of study is the lack of research investigating the effect of WCF on acquisition of explicit and implicit knowledge. In fact, research into the effect of WCF on explicit and implicit knowledge is in its infancy. In the previous studies examining the effect of WCF on improving the writing of learners, this issue is not considered and controlled which can overshadow the validity and reliability of the findings.

This finding is in contract with Shintani and Ellis (2013); however, it should be mentioned that their treatment, i.e., metalinguistic explanation, was different from the treatment of this study which was focused direct and indirect WCF.

According to the finding, it can be argued that focused direct WCF can lead to acquisition of explicit and implicit knowledge. The findings of the immediate and delayed posttests can be interpreted as an evidence for strong interface hypothesis which claims that explicit knowledge can be transferred into implicit knowledge. According to this position, L2 knowledge is first gained in explicit form as learned knowledge and then transferred into implicit one as acquired knowledge through communicative practice or conscious reflection and analysis (Zhang, 2015). It seems that the participants of this

Table 14 Results of one-way ANCOVA for timed grammaticality judgment test

\begin{tabular}{lllllll}
\hline Source & $S S$ & $d f$ & $M S$ & $F$ & $p$ & $\eta_{p}^{2}$ \\
\hline Pretest & 24.23 & 1 & 24.23 & 28.64 & .000 & .25 \\
Group & 30.59 & 2 & 15.30 & 18.08 & .000 & .30 \\
Error & 70.22 & 83 & .84 & & & \\
Total & 373.00 & 87 & & & & \\
\hline
\end{tabular}


study reflected on focused direct WCF and analyzed it which resulted in acquiring explicit and implicit knowledge of the target structure. However, due to the complexity of explicit and implicit knowledge and the intricate relationship between them, the findings should be interpreted with a great deal of caution. As it is stressed, the relationship between these two types of knowledge is not straightforward. Ellis (2008) stressed that the distinction between explicit and implicit knowledge is controversial; one of the debated issues is whether the relationship between these two types of knowledge is a continuum or a binary dichotomy. Bell (2017) found that extant binary classification of explicit and implicit learning is not adequate.

Also, acquisition of a target structure and transferring an explicit knowledge to implicit one takes time. Moreover, there might be a lot of mediating and intervening variables affecting the acquisition of explicit and implicit knowledge such as learners' individual differences such as aptitude, motivation, and learning styles.

\section{Limitations, implications, and suggestions for future research}

Like all studies, this study has its own limitations. This study should be conducted in different contexts of studies with more and different sample size to validate its findings. Future research should compare different kinds of WCF such as unfocused WCF and metalinguistic explanation. Moreover, regarding the nature of explicit and implicit knowledge, more longitudinal research including more treatment sessions can lead to different finding. Also, the research in this area should be replicated examining different target structures. Likewise, the effect of peer WCF in acquisition of explicit and implicit knowledge needs to be investigated.

Regarding the instruments used in this study, more research is needed to validate these instruments as measures of explicit and implicit knowledge. As Suzuki and DeKeyser (2017) highlighted, fine-grained measures of implicit and explicit knowledge are needed. Kim and Nam (2017) suggested that elicited imitation test is more valid instrument for measuring implicit knowledge than timed grammaticality judgment test. Likewise, Tomita, Suzuki, and Jessop (2009) considered elicited imitation test as a valid measure of implicit knowledge. Further research can use elicited imitation test to measure implicit knowledge which might yield different result. Using two new measures introduced by Suzuki (2017) and Vafaee, Suzuki, and Kachisnke (2017): self-paced reading task, word-monitoring task, visual-word task can result in different findings. Similarly, conducting this study in laboratory setting might have different results. Furthermore, future researchers should consider learners' zone of proximal development and scaffolding in WCF and choosing the target structure of the studies.

\section{Conclusion}

The aim of this study was to investigate the effect of direct and indirect WCF on explicit and implicit knowledge acquisition by Iranian beginner language learners in an EFL context. The data analysis indicated that providing focused direct WCF can result in acquisition of explicit and implicit knowledge of Iranian beginner language learners. However, this study should be replicated in different contexts with different learners and other target structures and tests and tasks as this issue: explicit and implicit 
knowledge acquisition is a very complicated issue with too many individual and contextual variables playing key roles in L2 knowledge acquisition and development.

In sum, as Polio (2012) highlighted, more research on the effect of WCF on developing learners' explicit and implicit knowledge is needed. As Kerz, Wiechmann, and Riedel (2017) argued, the role of awareness in SLA and explicit and implicit knowledge and learning is still an empirically unresolved issue which needs more in-depth robust experimental research.

As already discussed, to obtain a better understanding of the role of different strategies of WCF in explicit and implicit knowledge acquisition, we are in need of more longitudinal studies in various contexts with different learners at various age groups with different backgrounds. Also, we need to measure explicit and implicit knowledge with more valid and reliable instruments. Finally, replication research is needed in this field of study to validate the findings.

Abbreviations

L2: Second language; SLA: Second language acquisition; WCF: Written corrective feedback

\section{Acknowledgments}

We are thankful to the editorial board and the anonymous reviewers of Language Testing in Asia for their instructive feedback on this research paper.

Funding

The authors did not receive any funding support for this research.

Availability of data and materials

The data is available upon request from the corresponding author for using in further research. You may contact the corresponding author: Hassan Mohebbi (hassan.mohebbi973@gmail.com).

\section{Authors' contributions}

MN, SMA, and HM designed the study; HM conducted the study, collected the data, and analyzed it. MN and SMA revised the manuscript. All authors read and approved the final manuscript.

\section{Authors' information}

Majid Nemati is an associate professor in the Faculty of Foreign Languages and Literatures, University of Tehran, Tehran, Islamic Republic of Iran. His main research interests are form-focused instruction and corrective feedback. Sayyed Mohammad Alavi is a professor in the Faculty of Foreign Languages and Literatures, University of Tehran, Tehran, Islamic Republic of Iran. His main research interests are assessment and testing.

Hassan Mohebbi holds a PhD from the Faculty of Foreign Languages and Literatures, University of Tehran, Tehran, Islamic Republic of Iran. His main research interests are form-focused instruction, written corrective feedback, and assessment literacy.

https://orcid.org/0000-0003-3661-1690

https://scholar.google.com/citations?user=PIJIZoQAAAAJ\&hl=en

Email: hassan.mohebbi973@gmail.com

Competing interests

The authors declare that they have no competing interests.

\section{Publisher's Note}

Springer Nature remains neutral with regard to jurisdictional claims in published maps and institutional affiliations.

Received: 28 January 2019 Accepted: 15 April 2019

Published online: 23 May 2019

\section{References}

Akakura, M. (2012). Evaluating the effectiveness of explicit instruction on implicit and explicit L2 knowledge. Language Teaching Research, 16(1), 9-37.

Anderson, J. (1983). The architecture of cognition. Cambridge: Harvard University Press.

Anderson, J. (1985). Cognitive psychology and its implications (2nd ed.). New York: W. H. Freeman and Co..

Andringa, S., \& Rebuschat, P. (2015). New directions in the study of implicit and explicit learning. Studies in Second Language Acquisition, 37(2), 185-196.

Bell, P. K. (2017). Explicit and implicit learning: Exploring their simultaneity and immediate effectiveness. Applied Linguistics, 38(3), 297-317.

Bitchener, J. (2008). Evidence in support of written corrective feedback. Journal of Second Language Writing, 17(2), $102-118$. 
Bitchener, J. (2012). A reflection on 'the language learning potential' of written CF. Journal of Second Language Writing, 21(4), 348-363.

Bitchener, J., \& Knoch, U. (2008). The value of written corrective feedback for migrant and international students. Language Teaching Research, 12(3), 409-431.

Bitchener, J., \& Knoch, U. (2009a). The value of a focused approach to written corrective feedback. ELT Journal, 63(3), 204-211. Bitchener, J., \& Knoch, U. (2009b). The relative effectiveness of different types of direct written corrective feedback. System, $37(2), 322-329$.

Bitchener, J., \& Knoch, U. (2010). Raising the linguistic accuracy level of advanced L2 writers with written corrective feedback. Journal of Second Language Writing, 19(4), 207-217.

Bitchener, J., \& Knoch, U. (2015). Written corrective feedback studies: Approximate replication of Bitchener \& Knoch (2010a) and Van Beuningen, De Jong \& Kuiken (2012). Language Teaching, 48(3), 405-414.

Bitchener, J., Young, S., \& Cameron, D. (2005). The effect of different types of corrective feedback on ESL student writing. Journal of Second Language Writing, 14(3), 191-205.

DeKeyser, R. M. (1998). Beyond focus on form: Cognitive perspectives on learning and practicing second language grammar. In C. J. Doughty \& J. Williams (Eds.), Focus on form in second language acquisition (pp. 42-63). New York: Cambridge University Press.

Ellis, N. C. (2005). At the interface: Dynamic interactions of explicit and implicit language knowledge. Studies in Second Language Acquisition, 27(2), 305-352.

Ellis, R. (2002). Does form-focused instruction affect the acquisition of implicit knowledge? Studies in Second Language Acquisition, 24(2), 223-236.

Ellis, R. (2004). The definition and measurement of L2 explicit knowledge. Language Learning, 54(2), 227-275.

Ellis, R. (2005). Measuring implicit and explicit knowledge of a second language: A psychometric study. Studies in Second Language Acquisition, 27(2), 141-172

Ellis, R. (2008). Investigating grammatical difficulty in second language learning: Implications for second language acquisition research and language testing. International Journal of Applied Linguistics, 18(1), 4-22.

Ellis, R., Loewen, S., \& Erlam, R. (2006). Implicit and explicit corrective feedback and the acquisition of L2 grammar. Studies in Second Language Acquisition, 28(2), 339-368.

Ferris, D. R. (1995). Student reactions to teacher response in multiple-draft composition classrooms. TESOL Quarterly, 29(1), 33-53.

Ferris, D. R. (1997). The influence of teacher commentary on student revision. TESOL Quarterly, 31(2), 315-339.

Ferris, D. R. (1999). The case for grammar correction in L2 writing classes: A response to Truscott (1996). Journal of Second Language Writing, 8(1), 1-11.

Ferris, D. R. (2002). Treatment of error in second language student writing. Ann Arbor: The University of Michigan Press.

Ferris, D. R. (2003). Response to students writing: Implications for second language students. Mahwah: Lawrence Erlbaum.

Ferris, D. R. (2004). The "grammar correction" debate in L2 writing: Where are we, and where do we go from here? (and what do we do in the meantime ... ?). Journal of Second Language Writing, 13(1), 49-62.

Ferris, D. R. (2010). Second language writing research and written corrective feedback in SLA: Intersections and practical applications. Studies in Second Language Acquisition, 32(2), 181-201.

Ferris, D. R. (2012). Written corrective feedback in second language acquisition and writing studies. Lanquage Teaching, 45(4), 446-459.

Ferris, D. R. (2014). Responding to student writing: Teachers' philosophies and practices. Assessing Writing, 19, 6-23.

Ferris, D. R. (2015). Written corrective feedback in L2 writing: Connors \& Lunsford (1988); Lunsford \& Lunsford (2008); Lalande (1982). Language Teaching, 48(4), 531-544.

Godfroid, A., Loewen, S., Jung, S., Park, I., Gass, S., \& Ellis, R. (2015). Timed and untimed grammaticality judgments measure distinct types of knowledge: Evidence from eye movement patterns. Studies in Second Language Acquisition, 37(2), 269-397.

Gutierrez, X. (2013). The construct validity of grammaticality judgment tests as measures of implicit and explicit knowledge. Studies in Second Language Acquisition, 35(3), 423-449.

Han, Z. H., \& Finneran, R. (2014). Re-engaging the interface debate: Strong, weak, none, or all? International Journal of Applied Linguistics, 24(3), 370-389.

Heaton, J. (1975). Beginning composition through pictures. London: Longman.

Hill, L. A. (1988). Further stories for reading comprehension A. London: Longman.

Hulstijn, J. H. (2005). Theoretical and empirical issues in the study of implicit and explicit second language learning: Introduction. Studies in Second Language Acquisition, 27(2), 129-140.

Jacobs, H. L. (1981). Testing ESL composition: A practical approach. English composition program. Rowley: Newbury House Publishers, Inc.

Kerz, E., Wiechmann, D., \& Riedel, F. B. (2017). Implicit learning in the crowd: Investigating the role of awareness in the acquisition of L2 knowledge. Studies in Second Language Acquisition, 39(4), 711-734.

Kim, J., \& Nam, H. (2017). Measures of implicit knowledge revisited: Processing modes, time pressure, and modality. Studies in Second Language Acquisition, 39(3), 431-457.

Lee, I. (2013). Research into practice: Written corrective feedback. Language Teaching, 46(1), 108-119.

Li, S. (2014). The interface between feedback type, L2 proficiency, and the nature of the linguistic target. Language Teaching Research, 18(3), 373-396.

Pawlak, M. (2014). Error correction in the foreign language classroom: Reconsidering the issues. New York: Springer.

Pica, T. (1994). Research on negotiation: What does it reveal about second-language learning conditions, processes, and outcomes? Language Learning, 44(3), 493-527.

Polio, C. (2012). The relevance of second language acquisition theory to the written error correction debate. Journal of Second Language Writing, 21(4), 375-389.

Raimes, A. (1983). Techniques in teaching writing. USA: Oxford University Press.

Rezazadeh, M., Tavakoli, M., \& Eslami Rasekh, A. (2015). The effects of direct corrective feedback and metalinguistic explanation on EFL learners' implicit and explicit knowledge of English definite and indefinite articles. Journal of English Language Teaching and Learning, 16, 113-146.

Sarandi, H. (2015). Reexamining elicited imitation as a measure of implicit grammatical knowledge and beyond ...? Language Testing, 32(4), 485-501. 
Schmidt, R. (1990). The role of consciousness in second language learning. Applied Linguistics, 11(2), 129-158.

Sharwood Smith, M. (1981). Consciousness-raising and the second language learner 1. Applied Linguistics, 2(2), 159-168.

Sheen, Y. (2010). Differential effects of oral and written corrective feedback in the ESL classroom. Studies in Second Language Acquisition, 32(2), 203-234.

Shintani, N., \& Ellis, R. (2013). The comparative effect of direct written corrective feedback and metalinguistic explanation on learners' explicit and implicit knowledge of the English indefinite article. Journal of Second Lanquage Writing, 22(3), 286-306.

Shintani, N., Ellis, R., \& Suzuki, W. (2014). Effects of written feedback and revision on learners' accuracy in using two English grammatical structures. Language Learning, 64(1), 103-131.

Spada, N., Shiu, J. L., \& Tomita, Y. (2015). Validating an elicited imitation task as a measure of implicit knowledge: Comparisons with other validation studies. Language Learning, 65(3), 723-751.

Stefanou, C., \& Revesz, A. (2015). Direct written corrective feedback, learner differences, and the acquisition of second language article use for generic and specific plural reference. The Modern Language Journal, 99(2), 263-282.

Suzuki, Y. (2017). Validity of new measures of implicit knowledge: Distinguishing implicit knowledge from automatized explicit knowledge. Applied PsychoLinguistics, 38(5), 1229-1261.

Suzuki, Y., \& DeKeyser, R. (2017). The interface of explicit and implicit knowledge in a second language: Insights from individual differences in cognitive aptitudes. Language Learning, 67(4), 747-790.

Swain, M. (1985). Communicative competence: Some roles of comprehensible input and comprehensible output in its development. In S. Gass \& C. Madden (Eds.), Input in second language acquisition (pp. 235-253). Rowley: Newbury House.

Swain, M. (1995). Three functions of output in second language learning. In G. Cook \& B. Seidlhofer (Eds.), Principles and practice in the study of language (pp. 125-144). Oxford: Oxford University Press.

Tammenga-Helmantel, M., Arends, E., \& Canrinus, E. T. (2014). The effectiveness of deductive, inductive, implicit and incidental grammar instruction in second language classrooms. System, 45, 198-210.

Tomita, Y., Suzuki, W., \& Jessop, L. (2009). Elicited imitation: Toward valid procedures to measure implicit second language grammatical knowledge. TESOL Quarterly, 43(2), 345-350.

Truscott, J. (1996). The case against grammar correction in L2 writing classes. Language Learning, 46(2), 327-369.

Truscott, J. (1999). The case for "the case against grammar correction in L2 writing classes": A response to Ferris. Journal of Second Language Writing, 8(2), 111-122.

Truscott, J. (2001). Selecting errors for selective error correction. Concentric: Studies in English Literature and Linquistics, 27(2), 93-108.

Truscott, J. (2004). Evidence and conjecture on the effects of correction: A response to Chandler. Journal of Second Language Writing, 13(4), 337-343.

Truscott, J. (2007). The effect of error correction on learners' ability to write accurately. Journal of Second Language Writing, 16(4), 255-272.

Truscott, J. (2009). Arguments and appearances: A response to Chandler. Journal of Second Language Writing, 18(1), 59-60

Truscott, J. (2010). Some thoughts on Anthony Bruton's critique of the correction debate. System, 38(2), 329-335.

Vafaee, P., Suzuki, Y., \& Kachisnke, I. (2017). Validating grammaticality judgment tests: Evidence from two new psycholinguistic measures. Studies in Second Language Acquisition, 39(3), 431-457.

Van Beuningen, C., De Jong, N. H., \& Kuiken, F. (2012). Evidence on the effectiveness of comprehensive error correction in second language writing. Lanquage Learning, 62(1), 1-41.

Williams, J. (2012). The potential role(s) of writing in second language development. Journal of Second Language Writing, 21(4), 321-331.

Yan, X., Maeda, Y., LV, J., \& Ginther, A. (2016). Elicited imitation as a measure of second language proficiency: A narrative review and meta-analysis. Language Testing, 33(4), 497-528.

Zhang, R. (2015). Measuring university-level L2 learners' implicit and explicit linguistic knowledge. Studies in Second Language Acquisition, 37(3), 457-486.

\section{Submit your manuscript to a SpringerOpen ${ }^{\circ}$ journal and benefit from:}

- Convenient online submission

- Rigorous peer review

- Open access: articles freely available online

High visibility within the field

Retaining the copyright to your article

Submit your next manuscript at $\boldsymbol{\nabla}$ springeropen.com 